The Agriculturists 15(2):115-121(2017)ＩSSN 2304-7321 (Online), ISSN 1729-5211 (Print)

A Scientific Journal of Krishi Foundation

Indexed Journal

Impact Factor: 0.568 (GIF, 2015)

\title{
Seed Yield and Quality of Late Season Jute (Corchorus olitorius L.) Seed as Influenced by Plant Growth Regulators
}

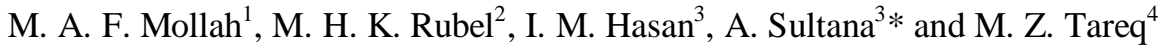 \\ ${ }^{1}$ Jute Research Regional Station, Bangladesh Jute Research Institute (BJRI), Rangpur, Bangladesh; \\ ${ }^{2}$ Depts. of Horticulture \& ${ }^{3}$ Plant Pathology Bangladesh Agricultural University (BAU), Mymensingh, \\ Bangladesh; ${ }^{4}$ Jute Agriculture Experimental Station, BJRI, Manikganj, Bangladesh \\ *Corresponding author and Email: af.sultana87@gmail.com
}

Received: 9 November 2017

Accepted: 22 December 2017

\begin{abstract}
An experiment was conducted at Jute Research Regional Station (JRRS) of Bangladesh Jute Research Institute (BJRI), Kishoreganj during August 2009 to January 2010 to determine the effect of different plant growth regulators on seed yield and quality of olitorius jute using late jute seed production technique. The experiment was laid out in a randomized complete block design (RCBD) with four replications. Seven growth regulators with different brand names such as Bionik, Litosen, Okozim, Mirakulan, Planovit, Flora and Yield were used in the experiment. All the yield contributing characters increased due to the application of growth regulators over the control. The highest seed yield (2.91g/plant) was obtained with Bionik which was followed by Mirakulan> Okozim> Litosen> Planovit> Yield> Flora> control. The highest of 33.49\% seed yield was found in Bionik over control. In terms of quality of seeds, the plant growth regulator 'Bionik' performed the best.
\end{abstract}

Keywords: Plant growth regulator (PGR), jute seed, yield, quality.

\section{Introduction}

Jute (Corchorus sp.) is the principal fiber crop of Bangladesh. It accounts for $6 \%$ of the foreign currency earnings from exports (Islam, 2009). Bangladesh is the largest supplier of jute and jute goods in the international markets meeting nearly $95 \%$ of world raw jute demand and about $60 \%$ of jute goods demand (Rahman, 2010). The green leaves of jute contain minerals and proteins, which are edible and are popular as leafy vegetable. Now a day's attempt is being made to popularize the jute plants also for making pulp in paper industries (Dastogeer et al., 2011). Among the various factors related to good production, seed quality plays the pivotal role. Quality seed of an improved variety itself can provide $20 \%$ additional jute yield (Hossain et al., 1994). Normal sowing time of olitorius jute is in the month of April for fiber production and August-September is the sowing time for seed production of olitorius jute but seed production during August-December known as 'late season jute seed production technique'. Unfortunately the availability of good quality jute seed in our country is far below than the total requirement. Farmers of the country often have to depend on market seed having poor quality. Hence, the production and quality of healthy jute seed as well as its quality storage is highly essential to ensure the higher yield of quality fiber in order to meet the challenging need for natural fiber. Bangladesh requires 40004500 MT of jute seed annually where as 
production in Bangladesh Agricultural Development Corporation (BADC) is only 8001000 MT. The farmers produce 400-600 MT. Rest of the demand is met up by importing mostly from India (Pulok et al., 2014). Nevertheless, the country has to largely rely on the farmers' seed and it faces acute scarcity of quality jute seed every year.

Plant Growth Regulators (PGRs) encompass a broad category of compounds that promote, inhibit, or otherwise modify plant physiological or morphological processes. Some PGRs are plant hormones or their analogues; others are simply metabolic regulators. PGRs are classified as organic compounds that alter the growth and development of plants. Plant growth regulators are used as stimulant in many crops to enhance the growth and yield of crops. Chemical PGRs have been widely used in cotton production in an attempt to adjust plant growth and to improve lint yield and fiber quality (Cothren and Oosterhuis, 2000). Now- a- days many growth regulators are available in our country. But the performances of growth regulators are not known for jute seed crops. From the above facts the experiment was designed to find out the effect of different plant growth regulators on seed yield and quality of olitorius jute under late jute seed production technique.

\section{Materials and Methods}

An experiment was conducted at the Bangladesh Jute Research Institute (BJRI), Regional Station, Kishoreganj, Bangladesh during the period from August to January 2009-2010. The site is located at $24^{\circ} 38$ North latitude and $90^{\circ} 13^{\prime}$ East longitudes and at an altitude of $18 \mathrm{~m}$. The soil of the site belongs to Old Brahmaputra Floodplain Agro Ecological Zone, 'AEZ-9' (UNDP and FAO, 1988). The field was medium high land having well-drained silty loam soil with $\mathrm{p}^{\mathrm{H}} 6.75$. The experimental field was prepared with three ploughings and cross ploughings followed by laddering. A randomized complete block design was used for this experiment with four replications.Seven growth regulators with different brand name such as Bionik, Litosen, Okozim, Mirakulan, Planovit, Flora and Yield were used in the experiment along with a control plot. The tested jute seed variety was O-72. The unit plot size was $4 \mathrm{~m} \times 3 \mathrm{~m}$. The climatic condition was hot and humid with frequent rain during vegetative phase, and cold and dry during the reproductive and ripening phase (Table 1). The crop was sown on 20 August, 2009. Line to line spacing was $30 \mathrm{~cm}$ and plant to plant spacing was $10 \mathrm{~cm}$. The crop was fertilized with urea, triple super phosphate, muriate of potash, gypsum and zinc sulphate @ $90 \mathrm{~kg} \mathrm{~N}, 20 \mathrm{~kg} \mathrm{P}$, $20 \mathrm{~kg} \mathrm{~K}, 18 \mathrm{~kg} \mathrm{~S}$ and $8 \mathrm{~kg} \mathrm{Zn} \mathrm{ha}^{-1}$, respectively. One third of urea and full amount of other fertilizers were applied as basal dose during final land preparation. The rest amount of urea was top dressed in two equal splits on 25 and 45 days after sowing (DAS). Plant growth regulators were applied at three different times of application i.e. vegetative at $70 \mathrm{DAS}$, flower initiation at $80 \mathrm{DAS}$ and pod initiation stage at 90 DAS of the crop. The growth regulators were applied by spraying at ten days interval. Solution was prepared according to company recommendation (Bionik@4ml/1L, Litosen@ 10ml/10L, Okozim @ 5ml/10L, Mirakulan@ 5ml/10, Planovit @15-20ml/10 L, Flora @ $5 \mathrm{ml} / 10 \mathrm{~L}$, Yield @1.5ml/10L of water). Spraying was done at the time of late afternoon.

All intercultural operations were done accordingly for off season seed production technique. Weeding was done by hand at 30 and 50 days after sowing (DAS). The crop plants were infested by caterpillar at vegetative stage. Insects were successfully controlled by spraying

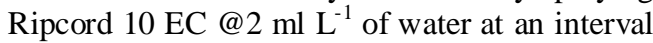
of 10 days. Removal of excessive rain water was done as and when necessary. The crop was harvested at maturity (when $80 \%$ capsules became brown). Plant height, base diameter, branch plant ${ }^{-1}$, pod plant ${ }^{-1}$, seed pod $^{-1}$ and seed yield plant ${ }^{-1}$ and different quality parameters i.e. 1000 -seed weight, germination\%, vigor index, accelerated ageing and field emergence were recorded. Seed yield and other plant characters were recorded from 10 randomly selected plants 
of each plot. The crop was harvested on 6-12 January in 2010. After harvest the crop was dried for three days and then threshed by beating with a stick. Seeds were cleaned and then dried for another five days in the sun to bring seed moisture content below $10 \%$ and stored properly in suitable air tight containers.

\subsection{Laboratory germination test}

The test was conducted on top of the paper method. The test was conducted on top of the paper method. One hundred seeds in four replications were placed on the moist paper (two fold of Bashundhara kitchen towel) in petridish (11 cm diameter). The petridishes were kept in the germinator maintain temperature at $30 \pm 1 \mathrm{oC}$. Daily counting of the germinating seedlings were done up to 8 days of seed setting. The number of normal seedling was counted at 8 DAS and the germination percentage of seed was measured with the following formula:

$$
\text { Germination }(\%)=\frac{\text { Number of normal seedling }}{\text { Number of seed sown }}
$$

\subsection{Vigour Index (VI)}

The number of germinated seeds was counted daily from the germination test up to 8 days. The seed vigour index (VI) was then calculated by following formula (AOSA, 1983):

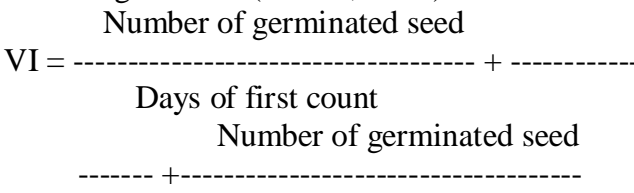

Days of final count

\subsection{Accelerated ageing (AA) test}

The test was done using $15 \mathrm{~g}$ of seed in accelerated ageing chamber exposing to $41^{\circ} \mathrm{C}$ temperature and $100 \%$ RH for 72 hours. Following the laboratory germination test (ISTA, 1999).

\subsection{0-seed weight}

1000 -seed weight was measured by using electric balance according to (ISTA, 1999).

\subsection{Field emergence (FE)}

Field emergence was calculated according to Mollah (2014) by using following formula:

$$
\begin{aligned}
& \text { Number of total seedling } \\
& \text { Field emergence }(\%)=--------------------\times 100
\end{aligned}
$$

\subsection{Statistical analysis of data}

The collected data on different yield related characters and seed quality parameters were subjected statistical analysis following ANOVA technique. Differences among treatment means were adjusted by Duncan's Multiple Range Test with the help of a computer based statistical package program MSTAT-C (Gomez and Gomez, 1984).

\section{Results and Discussion}

\subsection{Plant height}

Plant height is an important vegetative factor affecting seed yield. Plant growth regulators exerted significant effect on plant height over control. The tallest plant was recorded $(96.67 \mathrm{~cm})$ in Litosen which was statistically identical with Bionik but significantly higher than others (Table 2). Plant height of Okozim, Planovit and Yield were statistically similar but significantly lower than Mirakulan and Flora. The shortest plant was recorded $(80.63 \mathrm{~cm})$ in control treatment. Similar beneficial effects of plant regulators have been reported by several workers i. e., Chauhan et al. (2009) in black gram and horse gram and Somayeh and Alireza (2015) in wheat, Copur et al. (2010) in cotton, Akter et al. (2007) in mustard.

\subsection{Base diameter}

Plant growth regulators exerted significant effect on plant base diameter over control. The highest base diameter was recorded $(10.21 \mathrm{~mm})$ in Bionik which was significantly higher than control $(6.55 \mathrm{~mm})$ and Planovit but identical with other treatments. The lowest base diameter was recorded $(6.55 \mathrm{~mm})$ in control which was statistically similar with Planovit, Flora and Yield (Table 2). 
Table 1. Meteorological data recorded at the experimental site during the study period

\begin{tabular}{lllllll}
\hline Month & \multicolumn{2}{c}{ Air temperature (\%) } & $\begin{array}{l}\text { Rainfall } \\
(\mathrm{mm})\end{array}$ & $\begin{array}{l}\text { Relative } \\
\text { Humidity (\%) }\end{array}$ & $\begin{array}{l}\text { Sunshine } \\
\text { (hrs/day) }\end{array}$ & $\begin{array}{l}\text { Cloudy } \\
\text { (hrs/day) }\end{array}$ \\
\cline { 2 - 6 } & Max & Min & & & & \\
\hline August-2009 & 32.4 & 26.7 & 277 & 88.55 & 4.39 & 7.08 \\
September-2009 & 32.4 & 26.9 & 154 & 86.70 & 4.77 & 6.18 \\
October-2009 & 31.9 & 24.0 & 193 & 87.10 & 5.84 & 6.75 \\
November-2009 & 28.4 & 18.6 & 2.39 & 84.22 & 7.15 & 4.48 \\
December-2009 & 23.7 & 13.7 & 0.12 & 79.40 & 8.00 & 4.10 \\
January-2010 & 24.1 & 12.9 & 0.00 & 77.19 & 4.10 & 8.06 \\
\hline
\end{tabular}

Table 2. Effect of plant growth regulators on seed yield and yield contributing characters of olitorius jute variety O-72

\begin{tabular}{lccccccc}
\hline $\begin{array}{l}\text { Treatment } \\
\text { Growth } \\
\text { regulator })\end{array}$ & $\begin{array}{c}\text { Plant } \\
\text { height } \\
(\mathrm{cm})\end{array}$ & $\begin{array}{c}\text { Base } \\
\text { diameter } \\
(\mathrm{mm})\end{array}$ & $\begin{array}{c}\text { Branches/ } \\
\text { plant (no.) }\end{array}$ & $\begin{array}{c}\text { Capsules } \\
\text { /plant } \\
(\text { no. })\end{array}$ & $\begin{array}{c}\text { Seeds/ } \\
\text { capsule } \\
(\text { no. })\end{array}$ & $\begin{array}{c}\text { Seed } \\
\text { yield/ } \\
\text { plant }(\mathrm{g})\end{array}$ & $\begin{array}{c}\text { \% Yield } \\
\text { increase over } \\
\text { control }\end{array}$ \\
\hline Control & $80.63 \mathrm{e}$ & $6.55 \mathrm{~b}$ & $2.65 \mathrm{c}$ & $7.54 \mathrm{f}$ & $144.40 \mathrm{c}$ & $2.18 \mathrm{e}$ & - \\
Bionik & $96.00 \mathrm{a}$ & $10.21 \mathrm{a}$ & $3.13 \mathrm{ab}$ & $9.70 \mathrm{~b}$ & $170.13 \mathrm{a}$ & $2.91 \mathrm{a}$ & 33.49 \\
Litosen & $96.67 \mathrm{a}$ & $9.89 \mathrm{a}$ & $3.13 \mathrm{ab}$ & $9.23 \mathrm{c}$ & $173.00 \mathrm{a}$ & $2.59 \mathrm{bc}$ & 18.81 \\
Okozim & $82.97 \mathrm{~d}$ & $9.98 \mathrm{a}$ & $2.71 \mathrm{c}$ & $7.77 \mathrm{f}$ & $162.60 \mathrm{~b}$ & $2.69 \mathrm{~b}$ & 23.39 \\
Mirakulan & $88.23 \mathrm{~b}$ & $10.14 \mathrm{a}$ & $3.16 \mathrm{a}$ & $10.16 \mathrm{a}$ & $172.60 \mathrm{a}$ & $2.74 \mathrm{ab}$ & 25.69 \\
Planovit & $82.50 \mathrm{~d}$ & $8.24 \mathrm{~b}$ & $2.73 \mathrm{c}$ & $8.20 \mathrm{e}$ & $163.90 \mathrm{~b}$ & $2.46 \mathrm{~cd}$ & 12.84 \\
Flora & $85.63 \mathrm{c}$ & $8.96 \mathrm{ab}$ & $2.83 \mathrm{c}$ & $8.15 \mathrm{e}$ & $147.53 \mathrm{c}$ & $2.22 \mathrm{e}$ & 1.83 \\
Yield & $82.53 \mathrm{~d}$ & $8.16 \mathrm{ab}$ & $2.90 \mathrm{bc}$ & $8.63 \mathrm{~d}$ & $162.07 \mathrm{~b}$ & $2.36 \mathrm{de}$ & 8.26 \\
\hline CV(\%) & 1.21 & 19.46 & 5.50 & 2.01 & 1.48 & 5.49 & - \\
LSD $(0.05)$ & 1.54 & 2.52 & 0.24 & 0.25 & 3.54 & 0.20 & - \\
Level of sig. & $* *$ & $* *$ & $* *$ & $* *$ & $* *$ & $* *$ & \\
\hline
\end{tabular}

Table 3.Effect of plant growth regulators on the seed quality of olitorius jute variety O-72

\begin{tabular}{lccccc}
\hline $\begin{array}{l}\text { Treatment } \\
\text { (Growth } \\
\text { regulator) }\end{array}$ & $\begin{array}{c}\text { 1000-seed } \\
\text { wt. }(\mathrm{g})\end{array}$ & $\begin{array}{c}\text { Germination } \\
(\%)\end{array}$ & $\begin{array}{c}\text { Vigor Index } \\
(\%)\end{array}$ & $\begin{array}{c}\text { Accelerated } \\
\text { ageing } \\
\text { germination }(\%)\end{array}$ & $\begin{array}{c}\text { Field } \\
\text { emergence } \\
(\%)\end{array}$ \\
\hline Control & $1.894 \mathrm{bcd}$ & $86.50 \mathrm{ab}$ & $80.57 \mathrm{~cd}$ & $72.00 \mathrm{ab}$ & $84.50 \mathrm{ab}$ \\
Bionik & $2.008 \mathrm{a}$ & $89.75 \mathrm{a}$ & $85.23 \mathrm{a}$ & $75.00 \mathrm{a}$ & $87.00 \mathrm{a}$ \\
Litosen & $1.980 \mathrm{abc}$ & $88.25 \mathrm{ab}$ & $84.58 \mathrm{ab}$ & $74.00 \mathrm{ab}$ & $86.00 \mathrm{a}$ \\
Okozim & $1.891 \mathrm{bcd}$ & $85.50 \mathrm{ab}$ & $82.26 \mathrm{abcd}$ & $73.00 \mathrm{ab}$ & $83.75 \mathrm{ab}$ \\
Mirakulan & $1.986 \mathrm{ab}$ & $89.50 \mathrm{a}$ & $83.12 \mathrm{abc}$ & $74.00 \mathrm{ab}$ & $85.75 \mathrm{a}$ \\
Planovit & $1.867 \mathrm{~cd}$ & $84.75 \mathrm{ab}$ & $81.88 \mathrm{bcd}$ & $73.00 \mathrm{ab}$ & $83.00 \mathrm{ab}$ \\
Flora & $1.821 \mathrm{~d}$ & $85.50 \mathrm{ab}$ & $79.89 \mathrm{~d}$ & $70.00 \mathrm{~b}$ & $81.25 \mathrm{~b}$ \\
Yield & $1.872 \mathrm{bcd}$ & $83.25 \mathrm{~b}$ & $82.24 \mathrm{abcd}$ & $71.00 \mathrm{ab}$ & $83.50 \mathrm{ab}$ \\
\hline CV(\%) & 3.80 & 3.83 & 2.32 & 3.59 & 3.03 \\
LSD $(0.05)$ & 0.104 & 4.874 & 2.817 & 3.841 & 3.761 \\
Level of sig. & $* *$ & $*$ & $* *$ & $*$ & $* *$ \\
\hline
\end{tabular}

Note: $\mathrm{CV}=$ Coefficient of variation, $* *=$ Significant at $1 \%$ level, ${ }^{*}=$ Significant at $5 \%$ level. In a column, figures having similar letter(s) do not differ significantly at $5 \%$ level as per DMRT 


\subsection{Branches per plant}

Plant growth regulators exerted significant effect on the number of branches per plant over control. The highest number of branches per plant was recorded (3.16) in Mirakulan which was identical with Bionic and Litosen but significantly higher than others (Table 2). The lowest number of branches per plant was recorded (2.65) in control and it was statistically similar with Okozim, Planovit and Flora. Similar result was reported by Gare et al. (2017) in chilli.

\subsection{Capsules per plant}

Number of capsules per plant is an important seed yield contributing character. Plant growth regulators exerted significant effect on number of capsules per plant over control. The highest number of capsules per plant was recorded (10.16) in Mirakulan which was significantly higher than all other treatments (Table 2). The second highest number of capsules per plant was recorded in Bionic and it was significantly higher than others. Moderate number of capsules per plant was observed in Planovit and Flora, and the lowest number of capsule per plant was recorded (7.54) in control which was identical with Okozim (7.77). Similar results have been reported by several workers i.e., Copur et al. (2010) in cotton, Akter et al. (2007) in mustard.

\subsection{Seeds per capsule}

Number of seeds per capsule is another important seed yield contributing character. Plant growth regulators exerted significant effect on number of seeds per capsule over control. The highest number of seeds per capsule was recorded (173.00) in Litosen which was identical with Bionic and Mirakulan but significantly higher than other treatments. Seeds per capsules of Planovit, Okoimim and Yield were statistically identical which produces moderate number of seeds per capsules (Table 2). The lowest number of seeds per capsule was recorded (144.40) in control which was identical with Flora (147.53). Similar result was reported by Akter et al. (2007) in mustard.

\subsection{Seed yield per plant}

Plant growth regulators exerted significant effect on seed yield per plant over control. The highest seed yield per plant was recorded $(2.91 \mathrm{~g})$ in Bionik which was identical with Mirakulan but significantly higher than other treatments (Table 2). Seed yield of Mirakulan, Okozim and Litosen were identical. Again seed yield of Planovit and Litosen was identical. The lowest seed yield per plant was recorded $(2.18 \mathrm{~g})$ in control which was identical with Flora (2.22 g) and Yield (2.36 g). This might result from increased photosynthetic activity and the increased dry matter accumulation by the plant growth regulator, depending on the increase of photosynthetic pigments (Wu et al., 1994). Pan et al., (2013) reported that plant growth regulator spray has considerable effects on seed yield and quality. The present findings are in agreement with Ekamber and Kumar, (2007); Rajendra and Jones, (2009) in wheat, and Akter et al. (2007) in mustard.

\subsection{Yield increase}

Result revealed that commercial growth regulators have significant effect on seed yield and yield attributes of late jute seed production over control. The highest seed yield increase (33.49\%) over control was recorded by using Bionik which was followed $(25.69 \%)$ by using Mirakulam (Table 2). In terms of seed yield, the plant growth regulator 'Bionik' performed the best among the seven plant growth regulators used in this experiment.

\subsection{0-seed weight}

1000 -seed weight is considered both for yield and quality parameter of jute seed. Plant growth regulators exerted significant effect on 1000seed weight. The thousand seed weight ranged from $1.82 \mathrm{~g}$ to $2.00 \mathrm{~g}$ (Table 3). The highest 1000 -seed weight was recorded $(2.008 \mathrm{~g})$ in Bionik which was identical with Mirakulan $(1.986 \mathrm{~g})$ and Litosen $(1.980 \mathrm{~g})$ but significantly higher than other treatment. Moderate 1000-seed weight was recorded in control and Okozim. The lowest 1000-seed weight was recorded (1.821g) 
in Flora which was statistically identical with Yield and Planovt.

\subsection{Germination percentage}

Plant growth regulators exerted significant effect on seed germination percentage. The highest germination percentage was recorded $(89.75 \%)$ in Bionik which was statistically identical with Mirakulan (89.50\%) but significantly higher than Litosen (88.25\%), Control (86.50\%) and Okozim and Flora $(85.50 \%)$. The lowest germination percent was recorded in Yield $(83.25 \%)$ which was statistically lowest than others (Table 3). Similar result was reported by Tzortzakis (2009).

\subsection{Vigor index (VI)}

Plant growth regulators exerted significant effect on vigor index. The highest vigor index was recorded (85.23) in Bionik which was statistically identical with Litosen (84.58), Mirakulan (83.12), Okozim (82.26) and Yield (82.24). The lowest vigor index was recorded (79.89) in Flora which was statistically identical with control (80.57) but significantly lowest than others (Table 3 ).

\subsection{Accelerated ageing}

Plant growth regulators exerted significant effect on accelerated ageing. The highest accelerated ageing was recorded (75.00) in Bionik which was statistically identical but significantly highest than Mirakulan \& Litosen (74.00); Okozim \& Planovit (73.00); control (72.00) and Yield (71.00). The lowest was recorded (70.00) in Flora which was statistically lowest than others (Table 3). Moori and Eisvand (2017) reported that, pre-treatment of the non-aged and aged seeds by gibberellin improved the physiological quality of the seed and seedling.

\subsection{Field emergence}

Plant growth regulators also exerted significant effect on field emergence. The highest field emergence was recorded (87.00) in Bionik which was statistically identical with Litosen (86.00) and Mirakulan (85.75). The lowest was recorded (81.25) in Flora which was significantly lowest than others (Table 3). Similar result was reported by Tzortzakis (2009).

\section{Conclusions}

All the yield attributes increased significantly over the control due to the application of growth regulators. The highest seed yield $(2.91 \mathrm{~g} /$ plant $)$ was obtained with Bionik which was followed by Mirakulan> Okozim> Litosen> Planovit> Yield > Flora > control. Commercial plant growth regulators are not detrimental for seed quality and most of the growth regulators significantly increased seed quality of jute. Among the growth regulators, 'Bionik' performed the best in terms of increasing seed quality.

\section{References}

Akter, A., Ali, E., Islam, M. M. Z., Karim, R. and Razzaque, A. H. M. 2007. Effect of $\mathrm{GA}_{3}$ on growth and yield of mustard. International Journal of Sustainable Crop production, 2(2):16-20.

AOSA (Association of Official Seed Analysis). 1983. Seed Vigour Testing Handbook. Contribution No. 32 to the Handbook on Seed Testing, 285-296 pp.

Chauhan, J.S., Tomar, Y.K., Singh, N. I, Ali, S. and Debarati.2009. Effect of growth hormones on seed germination and seedling growth of black gram and horse gram. Journal of American Science, 5(5):79-84.

Copur, O., Demirel, U. and Karakus, M. 2010. Effects of several plant growth regulators on the yield and fiber quality of cotton (Gossypium hirsutum L.). Notulae Botanicae Horti Agrobotanici ClujNapoca, 38 (3): 104-110.

Cothren, J.S. and D.M. Oosterhuis. 2000. The use of plant growth regulators in cotton production. In: J.M. Stewart, D.M. Oosterhuis, and J. Heitholt (eds.). Handbook of Cotton Physiology, Kluwer Publisher, New York. (in press) 
Dastogeer, K.M.G., Ashrafuzzaman, M. and Ali, M.A. 2011. Study of transmission of the causal agent of leaf mosaic of jute. Bangladesh Journal of Seed Science and Technology, 15 (1\&2): 95-100.

Ekamber, K. and Kumar, M. P. 2007. Hormonal regulation of tiller dynamics in differentially-tillering rice cultivars. Plant Growth Regulation, 53:215-223.

Gare, B. N., Raundal, P. U. and Burli, A. V. 2017. Effect of plant growth regulators on growth, yield and yield contributing characters of rainfed chilli (Capsicum annuum L.). Advanced Agricultural Research \& Technology Journal, 1(2): 195-197.

Gomez, K.A. and Gomez., A.A. 1984. Statistical procedures for Agricultural Research 2nd Edn. John Willy and Sons., New York. 97-111pp.

Hossain, M. A., S. Haque, K. S. Sultana, M. M. Islam and A. L. Khandakar. 1994. Research on Late Jute Seed Production. Pub.Seed. Tech. Res. Bangladesh Jute Res. Inst., Dhaka. 176-178pp.

Islam, M.M. 2009. In: Jute seed technology. 1st edition. Pub. by Md. Mahmudul Islam, 397, Middle Monipur, Mirpur, Dhaka1216. College Gate Book Binding and Printing, Mohammadpur, Dhaka. 160p.

ISTA. 1999. International Rules for Seed Testing, 2003. Zurich, Switzerland, ISTA.126-131 pp.

Mollah, M. A. F. 2014. Yield and quality of kenaf seed as influenced by production and storage environment. $\mathrm{PhD}$ dissertation, Department of Seed Science and Technology. Bangladesh Agricultural University, Mymensingh. 56-60 pp.

Moori, S. and Eisvand, H. R. 2017. Plant growth regulators and ascorbic acid effects on physiological quality of wheat seedlings obtained from deteriorated seeds. Pakistan Journal of Botany, 49(5): 18111819.
Pan, S., Rasul, F., Li, W., Tian, H., Mo, Z., Duan, M. and Tang, X. 2013.Roles of plant growth regulators on yield, grain qualities and antioxidant enzyme activities in super hybrid rice (Oryza sativa L.). Rice Journal, 6(9): 1-10.

Pulok, M.A.I., Hossain, M.M., Mazed, H.E.M.K., Mahabub, S.T. and Sharmin, S. 2014. Effect of storage containers on the seed quality attributes of deshi jute (Corchorus capsularis L.) International Journal of Business, Social \& Scientific Research, 2(2): 100-103.

Rahman, M.M. 2010. Policy and prospect of jute and allied fibers with special reference to Bangladesh, Ministry of Textile \& Jute.Govt. of the People's Republic of Bangladesh, Bangladesh Secretariat. Dhaka.pp-2.

Rajendra, B. and Jones,J. D. G. 2009.Role of plant hormones in plant defense responses.Plant Molecular Biology, 69:473-488.

Somayeh, E. and Alireza, S. 2015. Effect of different gibberellic acid hormone levels on yield and yield components of wheat cultivars. Indian Journal of Fundamental and Applied Life Sciences, 5(2): 14761483.

Tzortzakis, N. G. 2009. Effect of pre-sowing treatment on seed germination and seedling vigour in endive and chicory. Horticultural Science (Prague), 36(3): 117-125.

UNDP and FAO (Food and Agricultural Organization). 1988. Land Resources Appraisal of Bangladesh for Agricultural Development. Report No. 2, Agroecological Regions of Bangladesh. 212$221 \mathrm{pp}$.

Wu, Z. L., Pan, Q. B.,Gao, Y. H., Wang, J. Y. and Wang, J. 1994. Technical researches on the all round chemical regulation of cotton plants. China Cottons, 21:10-11. 